\title{
Pamukta farklı ekim şekli ve ekim zamanının yeşilkurt (Helicoverpa armigera Hubn. Lepidoptera: Noctuidae) popülasyonuna ve bitki gelişmesine etkisinin araştırılması Ekrem ATAKAN $^{1 *} \quad$ Kenan BOYACl $^{2}$
}

Influence of various planting techniques and time on development of bollworm (Helicoverpa armigera Hubn. Lepidoptera: Noctuidae) and plant development in cotton

\begin{abstract}
The influence of various planting technique and time on the population developments of cotton bollworm (Helicoverpa armigera Hubn) in cotton was investigated in Adana province, Turkey in 2008-2009. Three planting techniques, ridge, flat and mulching were deployed. Cotton was planted at 15-days intervals in March-April period. There was two generations of the bollworm at boll forming-maturation period in July-August. Densities of bollworms in plots planted in mid- and late April were higher but significantly lower in plots planted in March $(P<0.05)$. Although larval densities, which appeared in plots planted in mid- and late April, and exceed 4-fold of the threshold level of bollworm in late July in 2009, decreased numbers of green bolls, this case did not reduce cotton yield in those plots; in reverse, cotton yields was the highest in all plots planted in mid-April. Yield of cotton sown at the latest date (late April) was the lowest. Although there were some differences, the highest cotton yield was obtained from the mulching technique (pooling over planting dates). Consequently, it is commented that planting of cotton by mulching technique in mid-April would be better cultural practice. If planting of cotton is getting late after April, damage due to the bollworm attacks would be increase with a high rate.
\end{abstract}

Keywords: Cotton, bollworm, development, planting techique, planting time

\section{Öz}

Farklı pamuk ekim şekilleri ve ekim zamanlarının yeşilkurt (Helicoverpa armigera Hubn.) populasyon gelişmesine etkisi Adana ilinde 2008 ve 2009 yıllarında araştııımıştır. Çalışmada sırta, düze ve malçlı olmak üzere üç ekim şekli kullanılmıştır. Pamukl mart-nisan döneminde 15 gün aralıklarla 5 farklı ekim zamanında ekilmiştir. Yeşilkurt, deneme parsellerinde Yeşilkurt pamuğun koza oluşturma ve olgunlaştırma döneminde ortaya çıkarak, temmuz - ağustos döneminde iki döl vermiştir. Yeşilkurt larva yoğunluğu tüm ekim şekillerinde nisan ayı ortası ve sonlarında ekilen parsellerde yüksek, mart ayında ekilen parsellerde ise önemli derecede düşük bulunmuştur $(P<0.05) .2009$ yılında temmuz ayı sonlarında ekonomik zarar eşiğinin 4 katı üzerine çıkan larva yoğunluğu, nisan ayı ortası ve sonunda ekilen parsellerde koza sayısını azaltmasına karşın $(P<0.05)$, nisan ortasında ekilen parsellerde verimi azaltmamış aksine, bu parsellerde verim en yüksek düzeyde gerçekleşmiştir. En son dönemde ekilen pamukta ise (nisan sonu) verim en düşük bulunmuştur. Bazı farklılıklara karşın, en yüksek verim malçlı ekim tekniğinden elde edilmiştir. Sonuç olarak, pamuğun malçı ekim tekniği ile nisan ayı ortasında ekilmesinin uygun olacağı, ve nisan ayından sonra, ekim zamanı geciktikçe, yeşilkurt zararının da o oranda artacağı kanaatine varıımıştır.

Anahtar sözcükler: Pamuk, yeşilkurt, gelişme, ekim tekniği, ekim zamanı

\footnotetext{
${ }_{2}^{1}$ Çukurova Üniversitesi, Ziraat Fakültesi, Bitki Koruma Bölümü, 01330, Sarıçam, Adana

${ }^{2}$ Adana Ticaret Borsası, Adana

"Sorumlu yazar (Corresponding author): eatakan@cu.edu.tr

Alınış (Received): 04.02.2017 Kabul ediliş (Accepted): 01.08.2017 Çevrimiçi Yayın Tarihi (Published Online): 12.12.2017
} 


\section{Giriş}

Pamuk ülkemizin en önemli sanayi bitkilerinden biri olup, 2016 yılı verilerine göre, ülkemiz genelinde 4.160,168 da alanda ekimi yapılarak, 756.008 ton ürün elde edilmiştir (Anonymous, 2016). Çukurova yöresi pamuk üretim alanlarının 1/4'ünü, üretimin ise $\% 55$ 'ini karşılamıştır. Devletin sağlamış olduğu destek ve pamuk fiyatındaki duruma göre, yörede pamuk üretiminde yıllara göre artış veya azalışlar olmaktadır.

Pamuk girdi maliyetleri yüksek olan kültür bitkisidir. Girdi maliyetlerinin dikkat alınabilir tutarını özellikle zararlı etmenlere karşı yapılan kimyasal mücadele masrafları oluşturmaktadır (Yurdakul et al., 1991). Çukurova'da en az 16 böcek veya akar türünün sorun olduğu bilinmektedir. Zararlı türler içerisinde yeşilkurt, Helicoverpa armigera Hubner (Lep.: Noctuidae) önemli bir zararlı olup, pamukta en az iki dölüne karşı ilaçlı mücadele yapılmaktadır (Mart et al., 2000). Zararlının larvaları pamuğun genaratif organlarıyla doğrudan beslenerek zararlı olmakta verim ve kaliteyi olumsuz etkilemektedir.

Yöremizde pamuk ekim alanlarında zararlılara karşı mücadele ağırlıklı olarak tarım ilaçları kullanılarak yapılmaktadır. İlaçlı mücadele yörede, doğal dengeyi faydalılar aleyhine bozmuştur (Özgür et al., 1988). Oysa yörede pamuk ekim alanlarında çok sayıda faydalı böcek ve akar türünün olduğu tespit edilmiştir (Ghavami, 1999). Dğer taraftan Güneydoğu Anadolu Bölgesi'ndeki pamuk ekiliş alanlarında yeşilkurt üzerinde baskı oluşturan faydalı organizmaların varlığı bildirilmiştir (Göven \& Efil, 1994; Özpınar \& Yücel, 2002). Pamukta zararlılara karşı mücadelelerin entegre mücadele disiplini içersinde yapılması önem arz etmektedir. Entegre mücadele çalışmalarında biyolojik mücadele kadar, kültürel tedbirlerin uygulanmasının da önemli bir yeri vardır. Bu tedbirler içerisinde ekim zamanı ve ekim şekli de yer almaktadır. Ülkemizde ekim zamanı ekim şekli gibi kültürel pratiklerin pamukta yeşilkurt üzerine etkileri konusunda şimdiye kadar yapılmış çalışmalara rastlanılmamakta birlikte, pamukta ekim zamanı ve ekim şeklinin dikenlikurt ve beyazsineğin popülasyon gelişmesinde önemli etkileri olduğu ortaya konulmuştur (İşler \& Özgür, 1992; Özpınar et al., 1998). Ülkemizde pamuk tarımında ekim zamanı ve ekim şeklinin bitki gelişmesine ve verime olan etkileri konusunda yapılmış çalışmalar bulunmaktadır (Şahin \& Ekşi, 1987; Çopur et al., 1999; Gür et al., 2001; Özpınar \& Işık, 2004)

Çukurova'da pamukta tarımında geç dönemde ortaya çıkan Lepidoptera takımından zararlılarına karşı geç ekimden sakınmak tavsiye edilmesine karşın, bu konuda gerek yörede ve gerekse ülkemizde oldukça sınırlı çalışmalar bulunmaktadır. Bununla birlikte, Pakistan'da pamuk tarlalarında ekim zamanının H. armigera populasyon gelişmesine etkileri araştırımıştır (Mustafa et al., 2004; Ali et al., 2009). Ancak, ekolojik faktörlerin farklılığından dolayı ekim şeklinin yeşilkurt üzerine etkileri bölgelere göre değişiklikler gösterebilir. Ekim teknikleri içerisinde malçlı ekim; verim artışı, erkencilik ve lif özelliklerinde artış sağlamasıyla son yıllarda üzerinde durulan bir konudur (Dong et al., 2003).

Bu çalışmada geç ekimden ziyade, özellikle malçlı ekim tekniğinden yararlanarak yapılan erken ekimin yeşilkurt'un popülasyon gelişmesine, bitki gelişimine ve verime olan etkilerinin araştırılması amaçlanmıştır. Elde edilen sonuçlar pamukta meyve organlarında beslenerek doğrudan verim kaybına neden olan yeşilkurt'un entegre mücadelesinde değerlendirilebilir ve sonuçlar benzer ekolojik koşullara sahip yörelere uyarlanabilir.

\section{Materyal ve Yöntem}

\section{Denemelerin kurulması}

Sırt yapma tekniğiyle 19 Kasım 2007 ve 20 Kasım 2008 tarihlerinde tohum yatağı oluşturulmuştur. Malçlı ve düze ekimler için her iki yılda Şubat ayı içinde 2 kez kültivatörle topraklar işlenmiş ve yabancı ot ilacıyla (trifluralin ) ile ilaçlanmıştır.

Ekimler bölünen bölünmüş parseller deneme desenine göre 3 tekrarlı olarak; 2008 yılında 01 mart (1. ekim), 15 Mart (2. ekim), 29 Mart (3. ekim), 15 Nisan (4. ekim) ve 28 Nisan (5. ekim); 2009 yılında ise 05 mart (1. ekim), 16 Mart (2. ekim), 30 Mart (3. ekim), 16 Nisan (4. ekim) ve 28 Nisan tarihlerinde düze, sırta ve malçlı ekimler şeklinde yapılmıştır. Deneme parseli 4 sıra $\times 0.76$ sıra arası $(\mathrm{m}) \times 13 \mathrm{~m}$ sıra uzunluğu olmak üzere $39.52 \mathrm{~m}^{2}$ olacak şekilde ayarlanmıştır. Plastik malçlı ekim için özel mibzerden faydalanıımıştır 
Tüm ekimlerde ekimle birlikte dekara $30 \mathrm{~kg} \mathrm{20-20-0} \mathrm{kompose} \mathrm{gübre} \mathrm{(N-P-K)} \mathrm{verilmiştir.} \mathrm{Tüm}$ parsellere ilk sudan önce dekara $10 \mathrm{~kg}$ saf azot gelecek şekilde üre (NH2-CO-NH2) uygulanmıştır. Malçlı ekimde bitkilerin çıkışları takiben (ekimden yaklaşık 15 gün sonra) plastik örtü kaldırılmıştır.

Tüm parsellerde; $1 ., 2$. ve 3 . sulamadan önce sırasıyla 30,40 ve $50 \mathrm{cc} /$ da olacak şekilde, bitki büyüme düzenleyicisi $\mathrm{Pix}^{\text {TM }}$ (1.1.1 dimethyl piperidinium chlorine) uygulanmıştır. 4. ve 5. ekim zamanlarında ekilen tüm parsellere 4. sulamadan önce $60 \mathrm{cc} / \mathrm{da}$ olacak şekilde Pix uygulaması yapılmıştır. Böylelikle, tüm ekim şekillerinde 1., 2. ve 3. ekim zamanlarını temsil eden parsellerde toplam $120 \mathrm{cc} / \mathrm{da} ; 4$. ve 5. ekim zamanlarındaki parsellerde ise toplam $180 \mathrm{cc} / \mathrm{da}$ olacak şekilde Pix uygulanmıştır. Denemelerde yeşilkurt'a karşı ilaçlama yapıımamıştır. Deneme parsellerinde ilaç kullanımı Çizelge 1'de gösterilmiştir.

Çizelge 1. Balcalı'da 2008 ve 2009 yıllarında deneme parsellerinde ilaç kullanımı

\begin{tabular}{lllll}
\hline İlaçlama tarihi & Ekim zamanı & İlaç (etken madde) & Dozu & Zararlı \\
\hline 9 Haziran & 29 Mart, 15 Nisan ve 28 Nisan & acetamiprid SP \%20 & $10 \mathrm{gr}$ & Yaprakpiresi \\
11 ve 12 Haziran & 15 Nisan ve 28 Nisan & acetamiprid SP \%20 & $10 \mathrm{gr}$ & Yaprakpiresi \\
2 ve 15 Ağustos & 15 Nisan ve 28 Nisan & acetamiprid SP \%20 & $40 \mathrm{gr}$ & Beyazsinek \\
\hline & & 2009 yılı & & Yaprakpiresi \\
\hline
\end{tabular}

\section{Yeşilkurt'un örneklenmesi}

Tüm ekim şekilleri ve ekim zamanlarında her parselin orta iki sırasından olmak üzere 2 adet $3 \mathrm{~m}$ sıra; tüm denemede ise toplam 6 adet $3 \mathrm{~m}$ pamuk sırası üzerindeki tüm bitkiler yeşilkurt'un yumurta ve larvaları için dikkatli bir şekilde incelenerek örneklenmiştir. Bulunan larvalar sayılarak kaydedilmiştir. Ergin örneklemesi yapılmamıştır. Örneklemeler haftalık aralıklarla saat 08:00 ile 11:00 arasında yapılmıştır.

\section{Yeşilkurt'un kozalardaki zararının saptanması}

Yeşilkurt örneklemesinin yapıldığı tarihlerde larva sayılarıyla birlikte vuruk kozalar da kaydedilmiştir. Bu amaçla tüm bitkilerde kozalar dikkatli bir şekilde incelenmiş, vuruk kozalarda larvalar aranmıştır. Vuruk, zarar görmüş fakat larva bulunamayan kozalar da vuruk koza olarak değerlendirilmiştir. Pamukta yeşilkurt gibi, pembekurt (Pectinophora gossypiella Saund.) larvaları da yeşil kozalarda zarar yapmaktadır. Yeşilkurt nedeniyle zarar görmüş kozalarda larva vurukları daha geniş delikler şeklinde görülürken pembekurt larvaları kozalarda daha küçük delikler açarak ve tüm vücut koza içersinde olacak şekilde beslenmektedir. Pembekurt ayrıca kozalarda ikiz çiğit oluşturarak zararlı olurken, yeşilkurt larvaları böyle zarara neden olmamaktadır. Her iki yılda tüm deneme parsellerinde az sayıda pembekurt larvaları kaydedilmiştir.

Yeşilkurt larvaları taraklarda da zarar yapmaktadır. Taraklarda yeşilkurt'un ilk dölünün zararı çoğunluk haziran ayı sonu-temmuz ayı başlarında görülmektedir. Vuruk taraklar kısa sürede yere düştüklerinden ve ayrıca tüm parsellerde taraklarda çok az sayıda larva bulunduğundan, yeşilkurt'un meyve organlarındaki zararının değerlendirmesinde tarak organı dikkate alınmamıştır.

\section{Yeşilkurt'un bitki gelişmesine ve verime etkisinin saptanması}

Her parselde seçilen bitkilerin boyu ölçülmüş, meyve dalı ve kozaları sayılmıştır. Pamuk bitkilerinin \%80'nin açılmasıyla her parselden 30 adet koza, budama makası yardımıyla alınarak kese kâğıdına konulmuştur. Böylelikle ortalama koza ağırıkları (gr) saptanmıştır. Daha sonra her parselde tüm bitkiler elle hasat edilmiştir. Parsel başına ortalama verim değerleri, dekara kütlü pamuk verimine dönüştürülmüştür. 


\section{Verilerin değerlendirilmesi}

Farklı ekim şekillerinde ekim zamanlarının ve yeşilkurt larva popülasyon gelişmesi ve vuruk koza sayısına etkileri, yenilemeli analiz testi (Repeated Measure-GLM ANOVA testi) ile $P<0.05$ önem seviyesinde incelenmiştir. Ortalamaların karşılaştırılması Tukey HSD testi ile $P<0.05$ önem seviyesinde yapılmıştır. Yeşilkurt'un vuruk koza sayısına etkisi, aynı analiz yöntemi kullanılarak değerlendirilmiştir. Farklı ekim zamanları ve ekim şekillerinin bitki generatif organ gelişmesi ve kütle verimine etkisi iki yönlü varyans analizi (GLM- Univarite testi) ile $\mathrm{P}<0.05$ testi ile incelenmiş olup, ortalamaların karşıllaştırılması tek yönü varyans analiz yöntemi (ANOVA) ile Tukey HSD testi $(P<0.05)$ kullanılarak yapılmıştır.

\section{Araştırma Bulguları}

\section{Ekim zamanlarının yeşilkurt larva popülasyon yoğunluğuna etkisi}

\section{8 yılı}

Ekim şekli ve ekim zamanı ve ayrıca ekim şekli ekim zamanı arasındaki interaksiyonunun yeşilkurt populasyon yoğunluğuna etkisi önemli bulunmuştur (Çizelge 2).

Çizelge 2. Adana ilinde 2008 ve 2009 yıllarında pamukta örnekleme tarihi, ekim şekli ve ekim zamanının yeşilkurt yoğunluğuna etkileri

\begin{tabular}{|c|c|c|c|c|c|}
\hline Yıl & Varyasyon kaynakları & sd & Kareler ortalaması & $\mathrm{F}$ & $\mathrm{P}$ \\
\hline \multirow[t]{9}{*}{2008} & Tarih & 14 & 48.913 & 138.711 & 0.000 \\
\hline & Tarih x ekim şekli & 28 & 2.461 & 6.978 & 0.000 \\
\hline & Tarih $x$ ekim zamanı & 56 & 14.308 & 40.577 & 0.000 \\
\hline & $\begin{array}{l}\text { Tarih } x \text { ekim şekli } x \text { ekim } \\
\text { zamanı }\end{array}$ & 112 & 1.944 & 3.648 & 0.000 \\
\hline & Hata (Tarih) & 1050 & 0.353 & & \\
\hline & Ekim şekli & 2 & 3.705 & 4.447 & 0.015 \\
\hline & Ekim zamanı & 4 & 30.302 & 49.809 & 0.000 \\
\hline & Ekim şekli x ekim zamanı & 8 & 3.106 & 2.818 & 0.043 \\
\hline & Hata & 74 & 1.608 & & \\
\hline \multirow[t]{9}{*}{2009} & Tarih & 14 & 99.851 & 257.561 & 0.000 \\
\hline & Tarih x ekim şekli & 28 & 4.675 & 12.059 & 0.000 \\
\hline & Tarih x ekim zamanı & 56 & 11.034 & 28.461 & 0.000 \\
\hline & $\begin{array}{l}\text { Tarih } x \text { ekim şekli } x \text { ekim } \\
\text { zamanı }\end{array}$ & 112 & 1.297 & 3.346 & 0.000 \\
\hline & Hata (Tarih) & 1036 & 0.388 & & \\
\hline & Ekim şekli & 2 & 7.701 & 20.657 & 0.000 \\
\hline & Ekim zamanı & 4 & 11.209 & 32.746 & 0.000 \\
\hline & Ekim şekli x ekim zamanı & 8 & 1.369 & 3.999 & 0.001 \\
\hline & Hata & 74 & 0.342 & & \\
\hline
\end{tabular}

İlk yeşilkurt larvaları sırta ekimde 5., düze ekimde 4. ve 5., malçlı ekimde ise 2. ekim zamanında kaydedilmiştir (Şekil 1A, B, C). Tüm ekimlerde esas larva yoğunlukları 20 Ağustos'tan sonra görülmeye başlamıştır. Sırta, düze ve malçlı ekimlerde Yeşilkurt larva yoğunluğu 9 Temmuz-20 Ağustos tarihlerinde ekim zamanlarına göre 0.16-0.66 larva/3 m sıra arasında değişmiş, bir başka deyişle ekonomik zarar eşiğinin (2 larva/ $3 \mathrm{~m}$ pamuk sırası) (EZE) altında olmuştur. Sırta ekim şeklinde 4. ve 5. ekim zamanlarında, 27 Ağustos, 3 ve 10 Eylül tarihlerinde larva yoğunluğu 1 veya 2 larva/ $3 \mathrm{~m}$ düzeyine ulaşmış olup, diğer ekim zamanlarına göre yüksek ve önemli bulunmuştur (sırasıyla, $F=3.311$, sd=4,25; $P<0.013 ; \quad F=4.750, s d=4,25 ; P=0.005 ; F=10.000, s d=4,25 ; P=0.000$ ). Düze ekim şeklinde ise 27 Ağustos'da 4. ekim zamanında larva yoğunluğu diğerlerine göre önemli olmuştur ( $F=6.224$, sd=4,25; $P=0.001$ ). Larva yoğunlularında esas ve önemli artışlar son örnekleme tarihinde (17 eylül tarihinde) görülmüş olup, her üç ekim şeklinin 4. ve 5. ekim zamanlarında larva yoğunlukları, EZE'nin 2-4.5 katı aşarak, diğer ekim zamanlarına göre yüksek ve önemli olmuştur (sırta ekim: $F=12.809$, sd=4,25; $P=0.000$; düze ekim: $F=39.818$, sd=4,25; $P=0.000 ;$ malçlı ekim: $F=45.054$, $s d=4,25 ; P=0.000$ ). 


\section{9 yılı}

Ekim şekli ve ekim zamanı ve ayrıca ekim şekli ekim zamanı arasındaki interaksiyonunun yeşilkurt larva populasyon yoğunluğuna etkisi önemli bulunmuştur (Çizelge 2). Tüm parsellerde 2008 yılına göre parsellerde daha az sayıda yeşilkurt larvası kaydedilmiş olup, larvaların parsellerdeki popülasyon değişimi de bir önceki deneme yılına göre farklılıklar göstermiştir. Üç ekim şeklinin tüm ekim zamanlarında bazı farklılıklara karşın larvaların popülasyon dalgalanmaları benzer olmuştur (Şekil 1A, B, C). 22 ve 27 Temmuzda larva yoğunlukları tüm ekim şekillerinin 3., 4. ve 5. ekim zamanlarında iki hafta süreyle EZE'nin üzerinde olmuştur. En yüksek ve istatistiksel olarak önemli larva sayıları; sırta ekim, düze ekim ve malçılı ekim şekillerinde 5. ekim zamanında 29 Temmuz'da kaydedilmiş olup (Şekil 1A, B, C), sırasıyla, $11.83 \pm 1.49,4.16 \pm 0.55$ ve $9.66 \pm 1.33 / 3$ m olmuştur (sırasıyla, $F=5.890, s d=4,25, P=0.002$; $F=29.750, s d=4,25, P=0.000 ; F=9.997, s d=4,25, P=0.000$ ). Ortalama larva sayıları tüm ekim şekillerinde 1. ve 2. ekim zamanlarında önemli seviyede düşük bulunmuştur. Sadece 12 Ağustos'ta düze ekim şeklinin 5. ekim zamanında larva yoğunluğu önemli ve yüksek bulunurken (Şekil 1B); 29 Temmuz'dan sonra, üç ekim şeklinde farklı tarihlerde ekilen parsellerinde larva yoğunlukları, bir çok örnekleme tarihinde düşük veya sıfır düzeyinde kalmıştır.
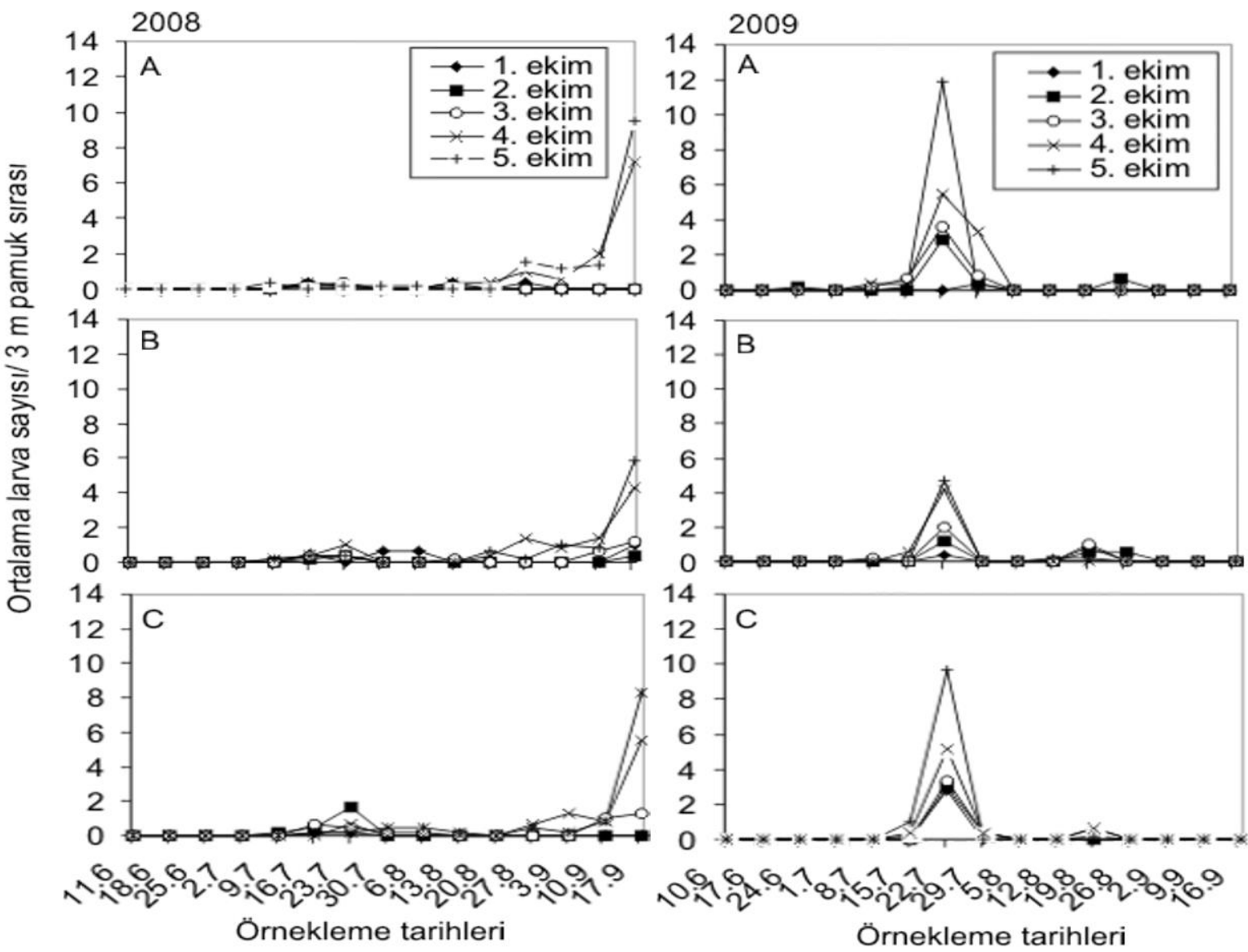

Şekil 1. Balcalı'da 2008 ve 2009 yıllarında sırta (A), düze (B) ve malçlı (C) pamuk ekim tekniklerinde 5 farklı ekim zamanında yeşilkurt'un larva popülasyon değişimi . 


\section{Ekim şekillerinin larva yoğunluğuna etkisi}

\section{8 yılı}

Ekim şekillerine göre her bir ekim zamanının yeşilkurt larva popülasyon yoğunlukların etkisi Şekil 2'de gösterilmiştir. Ekim şekli yönünden esas ve önemli farklılıklar, larva yoğunluğunun tüm ekim şekillerinde en yüksek olduğu 4. ve 5. ekim zamanlarında 17 Eylül tarihinde kaydedilmiştir (Şekil, 2D ve $2 E)$. 4. ekim zamanında sırta ekimde $(F=8.226$, $s d=2,15, P=0.002)$; 5 . ekim zamanında, ise sırta ve malçlı ekimde larva yoğunluğu önemli düzeyde yüksek bulunmuştur ( $F=9.856, \mathrm{sd}=2,15, \mathrm{P}=0.002)$. Diğer ekim zamanlarında ekim şekillerine göre istatistikî yönden önemli farklılıklar görülmemiştir.

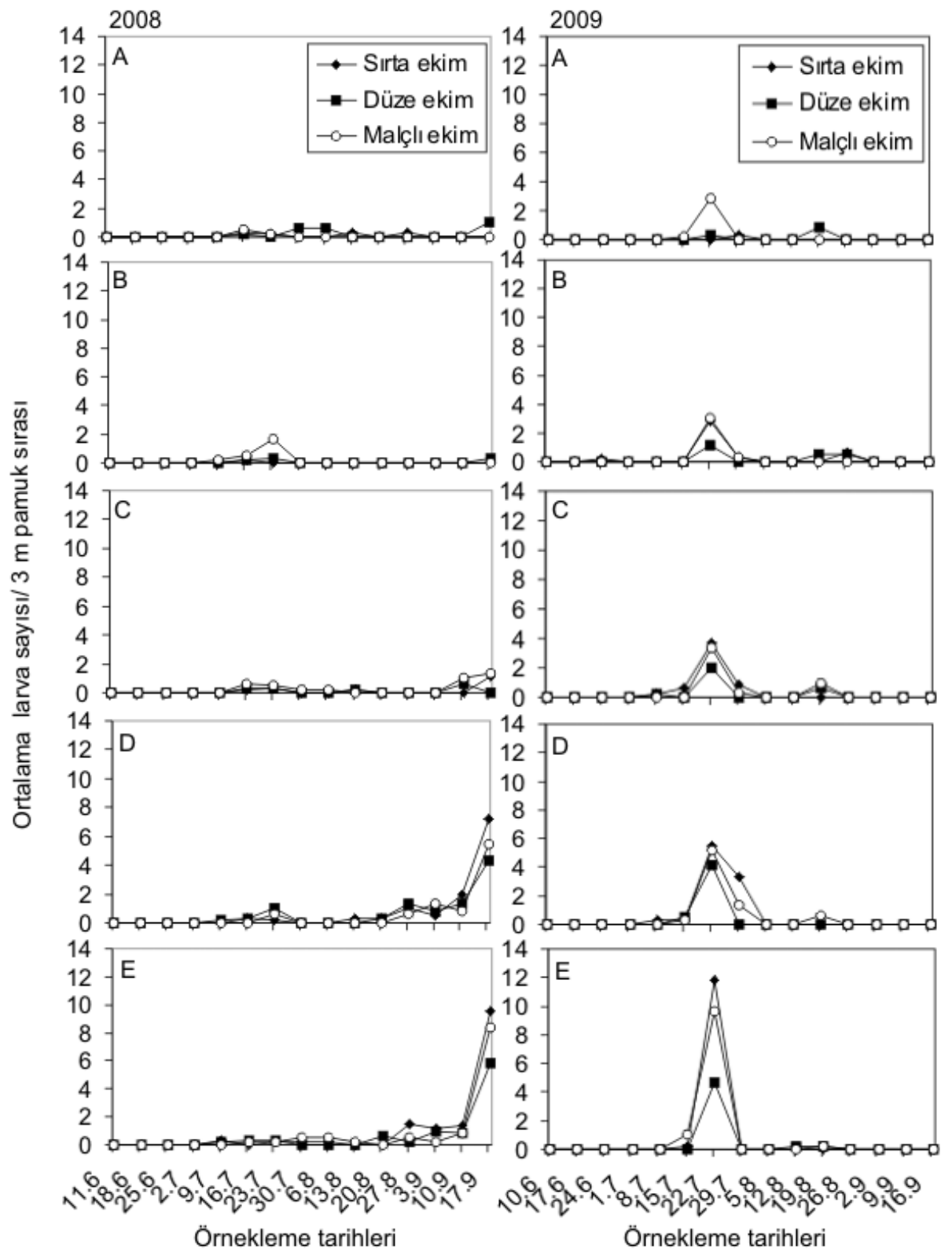

Şekil 2. Balcalı'da 2008 ve 2009 yıllarında pamukta sırta, düze ve maçlı ekim şekillerinde birinci (A), ikinci (B), üçüncü (C), dördüncü

(D) ve beşinci ekim (E) zamanlarında yeşilkurt'un larva popülasyon değişimi. 


\section{9 yılı}

Ekim şekillerine göre her bir ekim zamanının yeşilkurt larva popülasyon yoğunluğuna etkisi Şekil 2'de verilmiştir. Sırta ekim şeklinde üçüncü ekim zamanında 22 Temmuz da $(F=5.151$, sd=2,15, $P=0.020) ; 4$. ekim zamanında 29 Temmuz'da larva yoğunluğu önemli derecede yüksek bulunmuştur (Şekil 2D). Larva yoğunluğu 22 Temmuz tarihinde sırta ve malçlı ekim şekillerinde 5 . ekim zamanında benzer, ancak, düze ekime göre önemli derecede yüksek bululunmuştur $(F=9.398, s d=2,15, P=0.000$, Şekil 2E).

\section{Yeşilkurt'un kozalardaki zararının saptanması}

\section{8 yilı}

Ekim şekli ve ekim zamanı ve ayrıca ekim şekli ve ekim zamanı arasındaki interaksiyonunun vuruk koza sayısına etkileri önemli bulunmuştur (Çizelge 3). Farklı ekim şekillerinde, ekim zamanlarına göre ortalama vuruk koza sayıları şekil 2'de verilmiştir. Sırta ekimde ortalama vuruk koza sayısı 5. ekim zamanında 28 Ağustos, 3 ve 10 Eylül tarihlerinde önemli düzeyde yüksek bulunmuştur (sırasıyla, $F=8.350, s d=4,25, P=0.000 ; F=45.714$, $s d=4,25, P=0.000 ; F=4.000$, $s d=4,25, P=0.001$; Şekil $3 A$ ). $B u$ tarihlerde ortalama vuruk koza sayıları 1.50-2.66 adet/3 $\mathrm{m}$ arasında değişmiştir. Düze ekim şeklinde koza zararı 16-30 Temmuz tarihleri arasında dikkati çekmiş ve ortalama vuruk koza sayısı 2.00-2.83 adet /3 m olarak bulunmuştur (Şekil 3B). Malçlı ekimde en yüksek ortalama vuruk koza sayısı 27 Ağustos tarihinde

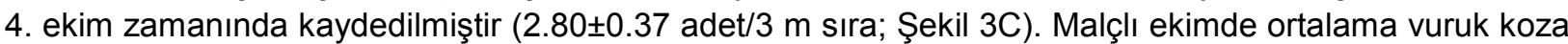
sayısının 4. ve 5. ekim zamanlarında benzer, ancak diğer ekim zamanlarına göre 6 Ağustos ( $F=6.44$, $\mathrm{sd}=4,25, \mathrm{P}=0.001), 27$ Ağustos $(\mathrm{F}=32.818, \mathrm{sd}=2,15, \mathrm{P}=0.000)$ ve 3 Eylül $(\mathrm{F}=23.793, \mathrm{sd}=4,25, \mathrm{P}=0.000)$ tarihlerinde daha ve yüksek ve önemli olduğu kaydedilmiştir.

Çizelge 3. Balcalı'da 2008 ve 2009 yıllarında pamukta ekim şekli ve ekim zamanının vuruk koza sayılarına etkileri

\begin{tabular}{|c|c|c|c|c|c|}
\hline Yıl & Varyasyon kaynakları & sd & Kareler ortalaması & $\mathrm{F}$ & $\mathrm{P}$ \\
\hline \multirow[t]{9}{*}{2008} & Tarih & 9 & 24.480 & 67.215 & 0.000 \\
\hline & Tarih x ekim şekli & 18 & 2.225 & 6.109 & 0.000 \\
\hline & Tarih $x$ ekim zamanı & 36 & 1.857 & 5.099 & 0.000 \\
\hline & $\begin{array}{l}\text { Tarih x ekim şekli } x \text { ekim } \\
\text { zamanı }\end{array}$ & 72 & 1.546 & 4.244 & 0.000 \\
\hline & Hata (Tarih) & 666 & 0.364 & & \\
\hline & Ekim şekli & 2 & 2.537 & 5.665 & 0.000 \\
\hline & Ekim zamanı & 4 & 18.766 & 41.907 & 0.005 \\
\hline & Ekim şekli x ekim zamanı & 8 & 1.621 & 3.620 & 0.000 \\
\hline & Hata & 74 & 0.448 & & \\
\hline \multirow[t]{9}{*}{2009} & Tarih & 9 & 78.208 & 268.090 & 0.000 \\
\hline & Tarih $\mathrm{x}$ ekim şekli & 18 & 1.755 & 3.589 & 0.000 \\
\hline & Tarih $x$ ekim zamanı & 36 & 6.210 & 21.287 & 0.000 \\
\hline & $\begin{array}{l}\text { Tarih } x \text { ekim şekli } x \text { ekim } \\
\text { zamanı }\end{array}$ & 72 & 1.356 & 4.647 & 0.000 \\
\hline & Hata (Tarih) & 666 & 0.292 & & \\
\hline & Ekim şekli & 2 & 0.995 & 3.142 & 0.049 \\
\hline & Ekim zamanı & 4 & 11.455 & 36.154 & 0.000 \\
\hline & Ekim şekli x ekim zamanı & 8 & 1.813 & 5.723 & 0.000 \\
\hline & Hata & 74 & 0.317 & & \\
\hline
\end{tabular}




\section{9 yılı}

Ekim şekli ve ekim zamanı ve ayrıca ekim şekli ve ekim zamanı arasındaki interaksiyonunun vuruk koza sayısına etkileri önemli bulunmuştur (Çizelge 3). Farklı ekim şekillerinde, ekim zamanlarına göre ortalama vuruk koza sayıları Şekil 3'de verilmiştir. Tüm farklı ekim şekilleri ve ekim zamanlarını temsil eden parsellerde vuruk kozalar, 22 Temmuz-5 Ağustos tarihleri arasında dikkati çekmiştir. Bir önceki yılın sonuçlarıyla genel bir değerlendirme yapıldığında; tüm ekim şekillerinde, 4. ve 5. ekim zamanlarında ortalama vuruk koza sayısı daha yüksek olup, 4 vuruk koza/ 3 m'nın üzerinde olmuştur. Sırta ekimde 29 Temmuz'da 4. ve 5. ekim zamanlarında benzer ve diğer ekimlere göre daha yüksek sayıda vuruk koza saptanmıştır $(F=10.994$, sd=4,25, $P=0.000$; Şekil $3 A)$. Düze ekim şeklinde 5. ekim zamanında 22 Temmuz'da $(F=3.673$, sd=4,25, $P=0.017) ; 29$ Temmuz'da ise 4. ve 5. ekim zamanlarında benzer ancak diğer parsellere göre önemli sayıda yüksek vuruk koza kaydedilmiştir $(F=12.853$, sd=4,25, $P=0.000$; Şekil 3B). Malçlı ekimde, 29 Temmuz'da 5. ekim zamanında en yüksek ve önemli sayıda vuruk koza (7.83 $\pm 0.30 / 3 \mathrm{~m}$ sıra) saptanmış olup ( $F=28.956, \mathrm{sd}=4,25, \mathrm{P}=0.000)$, bu değer tüm ekim zamanlarında en yüksek olanıdır (Şekil 3C).
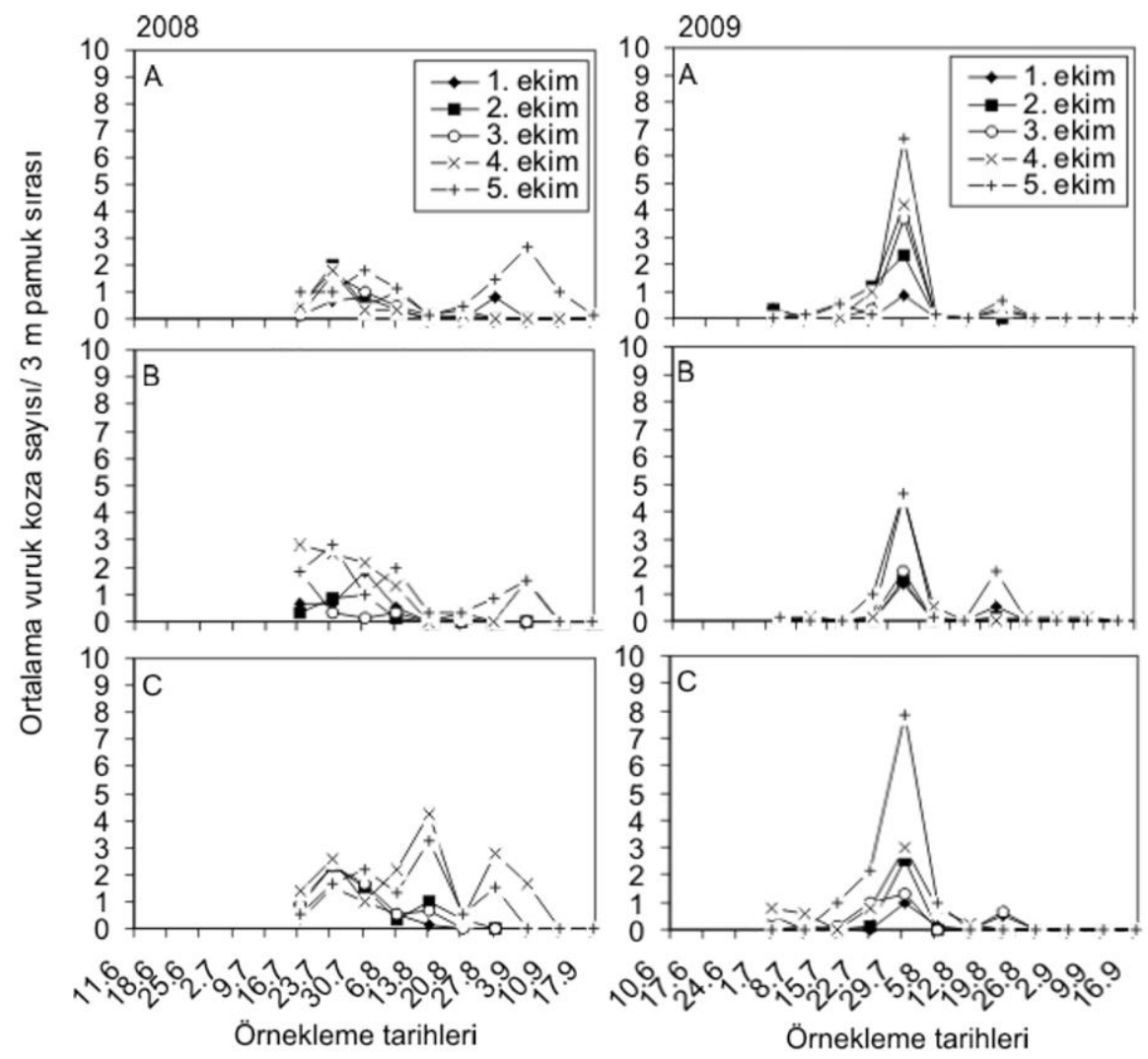

Şekil 3. Balcalı'da 2008 ve 2009 yıllarında sırta (A), Düze (B) ve malçlı (C) pamuk ekim tekniklerinde 5 farklı ekim zamanında ortalama vuruk yeşil koza sayıları.

\section{Ekim zamanının bitki gelişmesine ve verime etkisi}

\section{8 yılı}

Ekim zamanının bitkilerin vegatatif ve genaratif organ gelişmesine ve verime olan etkileri Çizelge 4'de gösterilmiştir. 
Düze, sırta ve malçlı ekim şekillerinin 4. ve 5. ekim zamanlarında; bitki boyu (sırasıyla, $F=171.056$, $\mathrm{sd}=4,10, \mathrm{P}=0.000 ; \mathrm{F}=199.428, \mathrm{sd}=4,10, \mathrm{P}=0.000 ; \mathrm{F}=110.947$, $\mathrm{sd}=4,10, \mathrm{P}=0.001$ ) ve meyve dalı sayıları (sırasıyla, $F=563.014$, sd=4,10, $P=0.000 ; F=501.431$, sd=4,10, $P=0.000 ; F=196.797$, $s d=4,10, P=0.000$ ) yüksek ve önemli bulunurken, ortalama koza sayıları 4. ekim zamanında daha yüksek ve önemli sayıda bulunmuştur (sırasıyla, $F=307.069$, $s d=4,10, \quad P=0.000 ; F=811.525, \quad s d=4,10, \quad P=0.000 ; \quad F=485.574$, $s d=4,10, P=0.000$ ). Kütlü pamuk ağırlıkları yönünden farklı ekim şekillerinde farklı ekim zamanlarında dikkate alınabilir farklııklar kaydedilmemiştir.

Çizelge 4. Balcalı'da 2008 yılında pamukta üç farklı ekim şeklinde ekim zamanının bitkilerinin vegatatif, generatif gelişmelerine ve verime olan etkisi ${ }^{\star}$

\begin{tabular}{lllllll}
\hline Ekim şekli & Ekim zamanı & $\begin{array}{l}\text { Bitki boyu } \\
(\mathrm{cm})\end{array}$ & $\begin{array}{l}\text { Meyve dalı } \\
\text { sayısı (adet) }\end{array}$ & $\begin{array}{l}\text { Koza sayısı } \\
\text { (adet) }\end{array}$ & $\begin{array}{l}\text { Açılmış koza } \\
\text { kütlü ağırlığı (gr) }\end{array}$ & $\begin{array}{l}\text { Verim (kg/da) } \\
\text { Düze ekim }\end{array}$ \\
& $1.01 / 03$ & $78.10 \pm 0.87 \mathrm{c}$ & $9.03 \pm 0.87 \mathrm{~d}$ & $12.96 \pm 0.12 \mathrm{~d}$ & $6.10 \pm 0.15 \mathrm{a}$ & $537.33 \pm 5.78 \mathrm{c}$ \\
& $2.15 / 03$ & $73.93 \pm 0.63 \mathrm{~b}$ & $9.23 \pm 0.30 \mathrm{~d}$ & $13.90 \pm 0.05 \mathrm{c}$ & $5.83 \pm 0.24 \mathrm{a}$ & $547.30 \pm 1.85 \mathrm{c}$ \\
& $3.29 / 03$ & $90.83 \pm 0.92 \mathrm{~b}$ & $11.00 \pm 0.10 \mathrm{c}$ & $17.16 \pm 0.06 \mathrm{~b}$ & $5.93 \pm 0.21 \mathrm{a}$ & $559.66 \pm 6.38 \mathrm{~b}$ \\
& $4.15 / 04$ & $95.63 \pm 0.38 \mathrm{a}$ & $11.60 \pm 0.10 \mathrm{~b}$ & $18.26 \pm 0.16 \mathrm{a}$ & $5.43 \pm 0.08 \mathrm{ab}$ & $643.66 \pm 6.96 \mathrm{a}$ \\
& $5.28 / 04$ & $96.03 \pm 0.97 \mathrm{a}$ & $14.26 \pm 0.13 \mathrm{a}$ & $12.36 \pm 0.06 \mathrm{~d}$ & $4.83 \pm 0.03 \mathrm{~b}$ & $539.00 \pm 1.85 \mathrm{c}$ \\
& $1.01 / 03$ & $74.73 \pm 0.84 \mathrm{~d}$ & $10.30 \pm 0.05 \mathrm{c}$ & $16.80 \pm 0.87 \mathrm{~b}$ & $5.63 \pm 0.20 \mathrm{a}$ & $509.33 \pm 5.78 \mathrm{c}$ \\
& $2.15 / 03$ & $91.03 \pm 1.01 \mathrm{bc}$ & $9.26 \pm 0.03 \mathrm{~d}$ & $15.26 \pm 0.06 \mathrm{c}$ & $5.66 \pm 0.12 \mathrm{a}$ & $514.66 \pm 5.50 \mathrm{c}$ \\
& $3.29 / 03$ & $88.50 \pm 0.33 \mathrm{c}$ & $11.00 \pm 0.10 \mathrm{~b}$ & $20.00 \pm 0.20 \mathrm{a}$ & $5.66 \pm 0.13 \mathrm{a}$ & $549.66 \pm 5.33 \mathrm{~b}$ \\
& $4.15 / 04$ & $97.53 \pm 0.94 \mathrm{a}$ & $11.16 \pm 0.13 \mathrm{~b}$ & $20.00 \pm 0.20 \mathrm{a}$ & $5.10 \pm 0.05 \mathrm{a}$ & $582.00 \pm 2.08 \mathrm{a}$ \\
& $5.28 / 04$ & $93.36 \pm 0.80 \mathrm{~b}$ & $12.10 \pm 0.05 \mathrm{a}$ & $14.36 \pm 0.06 \mathrm{~d}$ & $4.83 \pm 0.03 \mathrm{~b}$ & $476.33 \pm 5.20 \mathrm{~d}$ \\
Malçlı ekim ekim & $1.01 / 03$ & $75.63 \pm 0.68 \mathrm{c}$ & $9.53 \pm 0.03 \mathrm{~d}$ & $17.06 \pm 0.06 \mathrm{c}$ & $6.10 \pm 0.15 \mathrm{a}$ & $549.20 \pm 4.91 \mathrm{c}$ \\
& $2.15 / 03$ & $77.96 \pm 0.27 \mathrm{c}$ & $9.50 \pm 0.10 \mathrm{~d}$ & $15.73 \pm 0.03 \mathrm{~d}$ & $5.86 \pm 0.13 \mathrm{a}$ & $540.33 \pm 1.85 \mathrm{c}$ \\
& $3.29 / 03$ & $90.90 \pm 0.09 \mathrm{~b}$ & $11.10 \pm 0.10 \mathrm{c}$ & $19.66 \pm 0.16 \mathrm{~b}$ & $5.96 \pm 0.13 \mathrm{a}$ & $579.66 \pm 6.38 \mathrm{~b}$ \\
& $4.15 / 04$ & $92.73 \pm 1.01 \mathrm{~b}$ & $13.06 \pm 0.06 \mathrm{a}$ & $22.66 \pm 0.06 \mathrm{a}$ & $5.23 \pm 0.03 \mathrm{a}$ & $666.00 \pm 2.51 \mathrm{a}$ \\
& $5.28 / 04$ & $99.00 \pm 0.36 \mathrm{a}$ & $13.86 \pm 1.20 \mathrm{a}$ & $14.53 \pm 0.16 \mathrm{e}$ & $5.40 \pm 0.35 \mathrm{a}$ & $412.00 \pm 1.52 \mathrm{~d}$ \\
\hline
\end{tabular}

"Sütunlar incelendiğinde aynı harfi alan ortalamalar Tukey HSD testine göre $\mathrm{P}<0.05$ önem seviyesinde önemli değildir.

Verim düze, sırta ve malçlı ekimlerin 4. ekim zamanlarında en yüksek, 5. ekim zamanında en düşük kaydedilmiştir (sırasıyla, $F=175.588, s d=4,10, P=0.000 ; F=206.293, s d=4,10, P=0.000 ; F=100.666$, $\mathrm{sd}=4,10, \mathrm{P}=0.000$ )

\section{9 yılı}

Ekim zamanının bitkilerin vegatatif ve genaratif organ gelişmesine ve verime olan etkisi Çizelge 5'de verilmiştir.

Düze ve sırta ekim şekillerinin 3. 4. ve 5. ekim zamanlarında; (sırasıyla, $F=21.717$, $s d=4,10$, $P=0.000 ; F=15.918, s d=4,10, P=0.000$ ) maçlı ekimde ise 4. ve 5. ekim zamanlarında bitki boyu yüksek ve önemli olmuştur ( $F=11.165, \mathrm{sd}=4,10, P=0.001)$. Her üç ekim şeklinde (Düz, sırt ve malçı) meyve dalı sayıları 4. ve 5. ekim zamanlarında bazı farklııılara karşın yüksek olduğu görülmektedir (sırasıyla, $F=4.969$, sd=4,10, $P=0.001 ; F=5.123 .431$, $s d=4,10, P=0.001 ; F=6.321$, $s d=4,10, P=0.008)$. Koza sayıları düze, sırt ve malçlı ekimlerde 4. ekim zamanında daha yüksek bulunmuştur (sırasıyla, $F=6.025$, sd=4,10, $P=0.000 ; F=3.742, s d=4,10, P=0.041 ; F=10.018$, $s d=4,10, P=0.002$ ). Kütlü pamuk ağırlıkları, düze ekimin 1. $(F=48.955, s d=4,10, P=0.000)$, sırta ekimin 2. $(F=41.500, s d=4,10, P=0.000)$ ekim zamanında yüksek ve önemli bulunurken, maçlı ekimde 2. ve 3. ekim zamanlarında benzer, fakat diğerlerine ( $F=28.150$, $s d=4,10, P=0.000$ ) göre önemli derecede yüksek olmuştur. Kütlü pamuk ağırlıklarının her üç ekim şeklinde 5. ekim zamanında diğerlerine önemli düzeyde düşük bulunmuştur. 
Pamukta farklı ekim şekli ve ekim zamanının yeşilkurt (Helicoverpa armigera Hubn. Lepidoptera: Noctuidae) popülasyonuna ve bitki gelişmesine etkisinin araştırılması

Verim düze, sırta ve malçlı ekimlerin 4. ekim zamanlarında en yüksek, 5. ekim zamanında en düşük olarak kaydedilmiştir (sırasıyla, $F=189.804$, $s d=4,10, P=0.000 ; F=225.182$, sd=4,10, $P=0.000 ; F=254.739$, $\mathrm{sd}=4,10, \mathrm{P}=0.000)$.

Çizelge 5. Balcalı'da 2009 yılında pamukta üç farklı ekim şeklinde ekim zamanlarının pamuk bitkilerinin vegatatif, generatif gelişmelerine ve verime olan etkileri*

\begin{tabular}{|c|c|c|c|c|c|c|}
\hline Ekim şekli & Ekim zamanı & $\begin{array}{l}\text { Bitki boyu } \\
(\mathrm{cm})\end{array}$ & $\begin{array}{l}\text { Meyve dalı } \\
\text { sayısı (adet) }\end{array}$ & $\begin{array}{l}\text { Koza sayısı } \\
\text { (adet) }\end{array}$ & $\begin{array}{l}\text { Açılmış koza } \\
\text { kütlü ağırlığı } \\
(\mathrm{gr})\end{array}$ & $\begin{array}{l}\text { Kütlü verimi } \\
(\mathrm{kg} / \mathrm{da})\end{array}$ \\
\hline \multirow[t]{5}{*}{ Düze ekim } & 1. $5 / 03$ & $62.00 \pm 4.48 b$ & $11.00 \pm 0.57 b$ & $17.90 \pm 0.66 b$ & $6.00 \pm 0.05 a$ & $540.33 \pm 1.85 b c$ \\
\hline & $2.16 / 03$ & $72.00 \pm 2.51 b$ & $11.00 \pm 0.57 b$ & $16.00 \pm 0.57 b$ & $5.60 \pm 0.04 b$ & $550.00 \pm 6.08 b$ \\
\hline & $3.30 / 03$ & $88.93 \pm .2 .03 a$ & $12.93 \pm 0.63 a b$ & $17.00 \pm 1.15 a b$ & $5.60 \pm 0.04 b$ & $620.00 \pm 2.08 a$ \\
\hline & $4.16 / 04$ & $94.05 \pm 3.63 a$ & $13.00 \pm 0.57 a b$ & $22.46 \pm 0.32 a$ & $5.63 \pm 0.06 b$ & $629.66 \pm 6.96 a$ \\
\hline & $5.28 / 04$ & $93.03 \pm 1.01 a$ & $13.96 \pm 0.60 \mathrm{a}$ & $16.93 \pm 0.63 b$ & $5.03 \pm 0.06 c$ & $550.50 \pm 1.52 b c$ \\
\hline \multirow[t]{5}{*}{ Sırta ekim } & 1. $5 / 03$ & $72.13 \pm 2.54 c$ & $12.02 \pm 0.57 b$ & $14.90 \pm 0.66 c$ & $5.50 \pm 0.05 b$ & $529.66 \pm 5.33 c$ \\
\hline & $2.16 / 03$ & $85.00 \pm 2.08 b$ & $10.96 \pm 0.60 b$ & $16.75 \pm 0.98 b$ & $5.80 \pm 0.05 a$ & $540.00 \pm 6.08 c$ \\
\hline & $3.30 / 03$ & $95.05 \pm 2.08 a$ & $11.03 \pm 0.60 b$ & $17.10 \pm 0.57 b$ & $5.50 \pm 0.02 b$ & $585.00 \pm 2.08 b$ \\
\hline & $4.16 / 04$ & $90.25 \pm 2.88 a$ & $13.00 \pm 0.57 a$ & $21.25 \pm 1.15 a$ & $5.50 \pm 0.02 b$ & $660.00 \pm 6.66 a$ \\
\hline & $5.28 / 04$ & $91.03 \pm 2.08 a$ & $14.16 \pm 0.68 \mathrm{a}$ & $16.23 \pm 0.42 b$ & $5.05 \pm 0.01 \mathrm{c}$ & $520.00 \pm 1.85 c$ \\
\hline \multirow[t]{5}{*}{ Malçlı ekim } & 1. $05 / 03$ & $76.02 \pm 1.05 c$ & $10.20 \pm 0.27 b$ & $14.06 \pm 0.60 c$ & $5.60 \pm 0.05 b$ & $580.10 \pm 2.08 c$ \\
\hline & $2.16 / 03$ & $75.00 \pm 2.88 c$ & $11.00 \pm 0.57 b$ & $15.96 \pm 0.48 b c$ & $6.00 \pm 0.01 a$ & $600.13 \pm 6.65 c$ \\
\hline & $3.30 / 03$ & $85.10 \pm 3.05 b$ & $13.06 \pm 0.58 \mathrm{ab}$ & $17.90 \pm 0.57 \mathrm{~b}$ & $6.03 \pm 0.06 a$ & $671.12 \pm 7.23 b$ \\
\hline & $4.16 / 04$ & $90.00 \pm 2.88 a$ & $14.10 \pm 0.60 \mathrm{a}$ & $27.13 \pm 0.69 a$ & $5.60 \pm 0.05 b$ & $705.10 \pm 4.51 a$ \\
\hline & $5.28 / 04$ & $95.20 \pm 1.58 a$ & $15.25 \pm 0.71 \mathrm{a}$ & $18.13 \pm 0.43 b$ & $5.50 \pm 0.03 b$ & $500.26 \pm 5.50 c$ \\
\hline
\end{tabular}

* Sütunlar incelendiğinde aynı harfi alan ortalamalar Tukey HSD testine göre $\mathrm{P}<0.05$ önem seviyesinde önemli değildir.

Ekim zamanlarına göre farklı ekim şekillerinde kütlü pamuk verimleri Çizelge 6'de verilmiştir. Bazı farklıığa karşın, her iki yılda tüm ekim şekillerinde ortalama verim değerleri, 1. ekimden (1 veya 5 Mart) 4. ekim (15 veya 16 Nisan) zamanına kadar düzenli artarken son ekim tarihinde (28 Nisan) azalmıştır. Her iki yılda bazı farklılıklara karşın, malçlı ekimde verim daha yüksek olmuş, bunu düze ekim izlemiştir. Her iki yılda da sırta ekimde şeklinde tüm ekim tarihlerinde genelde en düşük verim elde edilmiştir.

Çizelge 6. Balcalı'da 2008 ve 2009 yıllarında pamukta ekim zamanlarına göre farklı ekim şekillerinde ortalama $( \pm S H)$ kütlü pamuk verimleri $(\mathrm{kg} / \mathrm{da})^{*}$

\begin{tabular}{llllllll}
\hline Yıl & Ekim zamanı & \multicolumn{3}{c}{ Ekim şekli } & \multicolumn{3}{c}{ Varyans analizi } \\
\hline & & Düze ekim & Sırta ekim & Malçı ekim & sd & F & $P$ \\
\hline \multirow{2}{*}{2008} & $1.01 / 03$ & $537.33 \pm 5.78 \mathrm{a}$ & $509.33 \pm 5.78 \mathrm{~b}$ & $549.20 \pm 4.91 \mathrm{a}$ & 2,8 & 14.082 & 0.005 \\
& $2.15 / 03$ & $547.30 \pm 1.85 \mathrm{a}$ & $514.66 \pm 5.50 \mathrm{~b}$ & $540.33 \pm 1.85 \mathrm{a}$ & 2,8 & 47.873 & 0.000 \\
& $3.29 / 03$ & $559.66 \pm 6.38 \mathrm{~b}$ & $549.66 \pm 5.33 \mathrm{c}$ & $579.66 \pm 6.38 \mathrm{a}$ & 2,8 & 43.973 & 0.000 \\
& $4.15 / 04$ & $643.66 \pm 6.96 \mathrm{~b}$ & $582.00 \pm 2.08 \mathrm{c}$ & $666.00 \pm 2.51 \mathrm{a}$ & 2,8 & 96.070 & 0.000 \\
& $5.28 / 04$ & $539.00 \pm 1.85 \mathrm{a}$ & $476.33 \pm 5.20 \mathrm{~b}$ & $412.00 \pm 1.52 \mathrm{c}$ & 2,8 & 382.276 & 0.000 \\
& $1.05 / 03$ & $540.33 \pm 1.85 \mathrm{~b}$ & $529.66 \pm 5.33 \mathrm{c}$ & $580.10 \pm 2.08 \mathrm{a}$ & 2,8 & 37.596 & 0.000 \\
& $2.16 / 03$ & $550.00 \pm 6.08 \mathrm{~b}$ & $540.00 \pm 6.08 \mathrm{~b}$ & $600.13 \pm 6.65 \mathrm{a}$ & 2,8 & 56.550 & 0.000 \\
& $3.30 / 03$ & $620.00 \pm 2.08 \mathrm{~b}$ & $585.00 \pm 2.08 \mathrm{c}$ & $671.12 \pm 7.23 \mathrm{a}$ & 2,8 & 233.726 & 0.000 \\
& $4.16 / 04$ & $629.66 \pm 6.96 \mathrm{c}$ & $660.00 \pm 6.66 \mathrm{~b}$ & $705.10 \pm 4.51 \mathrm{a}$ & 2,8 & 89.754 & 0.000 \\
& $5.28 / 04$ & $550.50 \pm 1.52 \mathrm{a}$ & $520.00 \pm 1.85 \mathrm{~b}$ & $500.26 \pm 5.50 \mathrm{c}$ & 2,8 & 16.596 & 0.004 \\
\hline
\end{tabular}

* Satırlar incelendiğinde aynı harfi alan ortalamalar Tukey HSD testine göre $\mathrm{P}<0.05$ önem seviyesinde önemli değildir. 


\section{Tartışma ve Sonuç}

Her deneme yılı kendi içinde değerlendirildiğinde her üç farklı ekim şeklinde farklı ekim zamanlarında yeşilkurt larvalarının mevsimsel popülasyon değişimleri benzer olmasına karşın, larva yoğunluklarında farklılıklar görülmüştür. Nisan ayında ekilen pamuklarda (4. ve 5. ekimler) larva yoğunlukları genelde yüksek ve diğer ekim tarihlerine göre aradaki fark önemli bulunmuştur. Bir başka deyişle mart ayında ekilen pamuklarda larva yoğunluğu daha düşük ve ekonomik zarar eşiğinin (2 larva / 3 m pamuk sırası) altında kalmıştır. Pakistan'da erken ekilen (nisan ayı) pamuklarda $H$. armigera yoğunluğunun haziran ayı başında ekilenlere göre yüksek olduğu bildirilmiştir (Mustafa et al., 2004). Hindistan'da pamukta yapılan bir çalışmada ise, şubat ve mart aylarında ekilen pamuklarda, yeşilkurt larva yoğunluğunun nisan sonu-mayıs ve haziran ayı başlarında ekilenlere göre daha yüksek bulunmuştur (Amjad et al., 2009). Farklı çalışmalardan elde edilen farklı sonuçlar, ülkelerarası ekolojik farklılıklar (iklim, bitki örtüsü, alternatif konukçu bitkiler gibi) ileri gelebilir.

Farklı ekim şekillerinin farklı ekim zamanlarında yıllara göre larva populasyon değişim ve yoğunlukları farklılıklar göstermiştir. Larvalar 2008 yılında esas olarak mevsim sonunda kozaların olgunlaşma döneminde, 2009 yılında mevsim ortasında koza oluşturma-olgunlaştırma döneminde kaydedilmişlerdir. Larva populasyon değişim ve yoğunluklarının yıllara göre farklı olmasının değişik nedenleri olabilir. Olası nedenlerden birinin, bitki tür çeşitliliği ile ilgisinin olduğu düşünülmektedir: 2008 yılında deneme parseli, deneme amaçlı olarak ekilen yerfıstığı, soya, susam ve mısır parsellerinin hemen yakınında kurulmuştur. 2009 yılında ise aynı saha içersinde olmasın karşın deneme alanlarından yaklaşık $1 \mathrm{~km}$ uzaktadır ve pamuk tek ürün olarak ekilmiştir. Bir başka deyişle deneme alanlarının hemen yakın çevresindeki ürün deseni yeşilkurt larva yoğunluğunu etkilemiş olabilir. Zengin bitki çeşitliliği yeşilkurt larvaları için alternatif konukçu, veya tuzak bitki olarak rol oynamış olabilirler. Zira, bu bitki türleri yeşilkurt'un da konukçusudurlar. Venugopal et al. (1995) H. armigera zararının ve yaygınlığının; pamuğun yerfıstığı, soya, börülce ve mug fasulyesi ile birlikte yetiştirildiğinde, pamuğun tek ürün olarak yetiştirildiğinden daha düşük olduğunu sonuçlandırmıştır. Chamuene et al. (2007) Mozambik'te pamuk; sorgum, peagon bezelyesi ve krotalon bitkileri ile birlikte şerit halinde (intercropping) ekildiğinde, pamuğun tek ürün olarak yetiştirildiği duruma göre, yeşilkurt larva yoğunluğunun daha düşük, faydalı yoğunluğunun ise daha yüksek olduğunu bildirmişlerdir. Diğer yandan zengin bitki çeşitliliği yeşilkurt'un doğal düşmanları içinde uygun koşulları yaratarak (beslenme, barınma, korunma ve alternatif avlar gibi) bunların aktivitesini artırmış olabilir (Landis et al., 2000; Gurr et al., 2005). Bu çalışmada amaçlanmamış olmasına karşın, yıllar arasında popülasyon yoğunluğu yönünden görülen farklılıkta bitki tür çeşitliliğinin etkisi düşünülebilir. Daha sağlıkı sonuçlara ulaşmak için bu konuya ilişkin çalışmaların yapılmasında fayda olduğu düşünülmektedir.

Ekim şekillerinin larva yoğunluğuna etkileri değerlendirildiğinde; larva yoğunlukları sırta, düze ve malçı ekim şekillerde mart ayının farklı tarihlerinde ekilen pamuklarda benzer ve düşük iken, sırta ve malçlı ekimin nisan ayı ortası ve sonlarında ekilen parsellerinde daha yüksek bulunmuştur. Özellikle malçlı ekim tekniğinin daha uygun toprak sıcaklığı ve nem sağlaması, ayrıca bu tür ekimlerde yabancı ot sorunun nispeten daha düşük oluşu (Fereres \& Goldhamer, 1991) daha sağlıklı bitki gelişmesi teşvik ederek generatif organ yükünün fazla olmasını sağlamış olabilir. Böylelikle, yeşilkurt erginlerini daha fazla yumurta bırakma için cezp etmiş olabilir.

Tüm ekim şekillerinde 2008 yılında mevsim sonunda ortalama vuruk koza sayıları 4. ve 5. ekim zamanlarında daha yüksek ve önemli bulunurken, 1. 2. ve 3. ekim zamanlarında düşük olmuştur. Mart ayında ekilen pamuklarda vuruk koza sayısının daha düşük olması, kozaların çoğunluğunun bu dönemde (eylül ayı) açılmış olmasıyla ilgili olabilir. 4. ve 5. ekim zamanlarında yüksek larva yoğunluğuna karşın, ortalama vuruk koza sayısı aynı oranda artmamıştır. Bu durum, mevsim sonunda yeşil kozaların büyük bir çoğunluğunun olgunlaşarak koza kabuğunun daha sertleşmiş olması sonuçta özellikle genç larvaların 
kozaların içerilerine girememiş olmasıyla açıklanabilir. 2009 yılında ortalama larva sayısı tüm ekim şekillerinde 1. ve 2. ekim zamanları hariç diğer ekim zamanlarında (mart sonunda, nisan ayı içinde ekilen pamuklarda) yüksek ve önemli olmuştur. 2008 yılına göre daha yüksek larva yoğunluğuna paralel olarak vuruk koza sayısı da bir önceki yılın yaklaşık 2 katı olmuştur. Bir başka deyişle Temmuz ayı içinde görülen yeşilkurt larvaları, mevsim sonunda ortaya (2008 yılı eylül ayı) çıkanlara göre, bitki generatif organ gelişmesini daha fazla olumsuz etkilemiştir.

Farklı ekim şekillerinde farklı tarihlerde ekilen pamuklarda bitki vegatatif ve genaratif organ gelişmeleri ve verimleri de önemli düzeylerde farklı olmuştur. Bitki generatif organ sayısının (yeşil koza sayısı), genelde tüm ekim tekniklerinde, nisan ortasında ekilen pamuklarda, diğerlerine göre daha yüksek olduğu görülmektedir. Tüm ekim tekniklerinde en geç ekilen parsellerde (5. ekim zamanı) genaratif organ sayısı en erken ekilenlere göre genelde benzer olmasına karşın, verimin daha düşük olduğu görülmektedir. Çukurova'da iklim koşullarına bağlı olarak pamuğun normal ekim tarihleri 15 Nisan-15 Mayıs tarihleri arasındadır. Tüm parsellerin diğer zararlılardan benzer düzeyde etkilendiğini düşündüğümüzde, tüm ekim şekillerinde nisan ayında ekilen ve normal ekim olarak nitelendirilen ekim zamanlarında (4. ve 5. ekim zamanları) larva yoğunlukları ekonomik zarar eşiğinin üzerinde olmasına karşın, verimde belirgin düşüşler olmamıştır; aksine, verimin en düşük olduğu parsellerde bile ortalama verim değerleri, sulu ekimlerde, bölge değerleri arasında kalmıştır (450-550 kg/da). Bunun bir nedeninin, yeşilkurt'un 2008 yılında mevsim sonunda ortaya çıkması, 2009 yılında ise bitkinin kritik gelişme dönemin larva yoğunluğunun iki hafta sureyle EZE'nin üzerinde olmasıyla ilgisi olduğu düşünülmektedir. Bu bağlamada kritik gelişme döneminde de olsa temmuz ayı sonlarında ortaya çıkan ve EZE'ni iki hafta süreyle geçen yeşilkurt yoğunluğuna karşı nisan ayı ortasında ekilen pamuklarda (4. ekim) ilaçı mücadele yapılmamasının bitki gelişmesine olumsuz bir etkisinin olmayacağı söylenebilir. Bununla birlikte, her üç ekim şeklinde, nisan ayı sonlarında ekilen pamuklarda yeşilkurt beslenmesi nedeniyle verimin daha düşük olması sebebiyle nisan ayı sonlarından başlayarak ekim zamanı geciktikçe pamuklarda yeşilkurt zararının artacağı ve verimin de o oranda olumsuz etkilenebileceği tahmin edilebilir.

Bu çalışmada, malçlı ekim de dahil, mart ayındaki erken ekimlerde larva yoğunlukları daha düşük olmasına karşın, verim daha yüksek olmamıştır. Bununla birlikte, erken olarak ekilen pamuklar normal ekilenlere nispeten daha erken bir sürede hasat olgunluğuna erişmişlerdir. Erken ekilen pamukların kozaları biraz daha ağır olmasına karşın, bunun verime de olumlu etkisi olmamıştır. Namken \& Heilman, (1973) ve Quisenberry \& Roark, 1976'e göre; yetişme süreleri kısa olan erkenci genotiplerin yetiştirilmesi avantajı olmakla birlikte, verimde belli oranlarda düşüşler olmakta, erken olgunlaşan çeşitler düşük lif özelliklerine sahip olabilmektedirler. Her bir ekim şeklinde tüm ekim zamanları birlikte değerlendirildiğinde Malçlı ekim tekniğinde bazı farklılıklara karşın verim daha yüksek olup, bunu ikinci sırada düze ekim izlemiştir (Çizelge 6). Malçlı ekim özellikle erken ekimlerde (mart ayı) pamuk bitkilerinin çıkış problemini gidermektedir. Nisan ayında ekilen pamuklarda toprak sıcaklığı çıkış için uygun olacağından, malçı ekim öncelikli olmayabilir. Bununla birlikte, maliyet analizleri yapılarak, uygun olması durumunda normal ekimlerde de bu ekim tekniği önerilebilinir.

Sonuç olarak, mart ayında ekilen pamuklarda yeşilkurt larva yoğunlukları önemli derecede düşük olmasının verime olumlu bir etkisi olmamıştır. Malçlı ekimle erken ekimlerin bitki gelişmesine dolayısıyla verime katkıları görülmemiştir. Nisan ortasında ekilen pamuklarda temmuz ayında koza oluşturma döneminde ortaya çıkan ve ekonomik zarar eşiğini iki hafta süreyle aşan yeşilkurt yoğunluğunun verime olumsuz bir etkisi olmamıştır. Bununla birlikte, nisan ayı ortasından sonra ekim zamanı geciktikçe yeşilkurt zararının o nispette artabileceği tahmin edilebilir. Elde edilen verilere dayanarak, Çukurova'da pamuğun nisan ayının ilk haftalarında malçlı ekim tekniği ile ekilmesinin uygun olacağı kanaatine varılmıştır. 


\section{Yararlanılan Kaynaklar}

Anonymous, 2016. Bitkisel üretim istatistikleri. Türkiye İstatistik Kurumu (TÜIK). (web sayfası: http://www. tuik.gov.tr) (Erişim tarihi: Temmuz, 2017)

Amjad, A., G. M. Aheer, S. Muhammed, S. Zafar, A. Muhammed \& M. Khan, 2009. Effect of sowing dates on population development of Helicoverpa armigera $(\mathrm{Hb}$.) in cotton genotypes. Pakistan Entomologist, 31 (2): 128-132.

Chamuene, A., C. Ecole \& A. Sidumo, 2007. "Effect of strip intercropping for management of the American bollworm, Helicoverpa armigera Hubner (Lepidoptera: Noctuidae) on cotton (Gossypium hirsutum) in Morrumbala District”, pp. 1049-1052. 8th African Crop Science Society Conference, El-Minia, Egypt, 27-31 October 2007.

Çopur, O., M. Oğlakçı \& M. A. Gür, 1999. "Harran Ovası koşullarında farkıı ekim zamanlarının pamuk (Gossypium hirsutum L.) lif teknolojik özelliklerine etkisi üzerine bir araştırma", 98-102. Türkiye 3. Tarla Bitkileri Kongresi 15-18 Kasım 1999, Adana.

Dong, H. Z., W. J. Li, Z. H. Li, W. Tang \& D. M. Zhang, 2003. Review on utilization of vegetative branches of cotton plants. Cotton Science, 15:313-317.

Fereres, E. \& D. A. Goldhamer, 1991. Plastic mulch increases cotton yield, reduces need for preseason irrigation. California Agriculture, 45(3): 25-28.

Ghavami, M. D., 1999. "Adana ili Karataş ve Balcalı pamuk tarlalarında doğal düşman türlerinin saptanması", 541552. Türkiye IV. Biyolojik Mücadele Kongresi Bildirileri 26-29 Ocak 1999, Adana.

Göven, M. A. \& L. Efil, 1994. "Dicle vadisi pamuk alanlarında zararlı yeşilkurt (Heliothis armigera Hübn.) (Lepidoptera: Noctuidae)'un doğal düşmanları ve etkinlikleri üzerinde araştırmalar", 449-457. Türkiye 3. Biyolojik Mücadele Kongresi Bildirileri, 25-28 Ocak, İmir.

Gurr, G. M., S. D. Wratten, J. M. Tylianakis, J. Kean \& M. Keller, 2005. Providing plant foods for natural enemies in farming systems: balancing practicalities and theory. In: Plant-Provided food for Carnivorous Insects: a protective mutualism and its application (Ed: Wäckers FL, van Rijn P.C. J, Bruin J ). Cambridge University Press,Cambridge, U.K., pp 326-347.

Gür, M. A., O. Çopur, A. Özel \& M. Oğlakçı, 2001. "Harran ovası koşullarında farklı ekim zamanlarının pamuk (Gossypium hirsutum L.) bitkisinde verim tarımsal özellikler ve erkencilik kriterlerine etkisi üzerine bir araştırma",175-180. I. Türkiye Tarla Bitkileri Kongresi 17-21 Eylül 2001, Tekirdağ.

İşler, N. \& A. F. Özgür, 1992. Farklı ekim zamanı ve ekim şeklinin pamukta Beyaz Sinek (Bemisia tabaci Gen.) populasyonuna, bitki gelişmesine ve pamuk verimine etkisi üzerine araştırmalar. Türkiye Entomoloji Dergisi, 16 (2):87-98.

Landis, D. A., S. D. Wratten \& G. M. Gurr, 2000. Habitat management to conserve natural enemies of arthropod pests in agriculture. Annual Review of Entomology, 45: 175-201.

Mart, C., M. M. Aslan, N. Eroğlu \& O. Doğanlar, 2000. Pamuk alanlarında yeşilkurt, Heliothis armigera Hbn (Lepidoptera: Noctuidae)'un popülasyon takibinde eşeysel çekici tuzakların kullanım imkanları üzerinde araştırmalar. Kahramanmaraş Sütçü Imam Üniversitesi Fen ve Mühendislik Dergisi, 3(2): 145-153.

Mustafa, G., A. Nasreen, M. Ashfag \& Q. Ali, 2004. Management of Helicoverpa armigera (Hubner) on cotton by host plant resistance and sowing time. Pakistan Journal of Biological Sciences, 7 (10): 1767-1771.

Quisenberry, J. E. \& B. Roark, 1976. Influence of determinate growth habit on yield and irrigation water-use efficiency in upland cotton. Crop Science, 16: 762-765.

Namken, L. N. \& M. D. Heilman, 1973. Determinant cotton cultivars for more efficient cotton production on medium textured soils in the lower Rio Grande valley of Texas. Argonomy Journal, 65: 953-956.

Özgür, F. A., E. Şekeroğlu, O. Gençer, H. Göçmen, D. Yelin \& N. İşler, 1988. Önemli pamuk zararılıarının pamuk çeşitlerine ve bitki fenolojisine bağlı olarak popülasyon gelişmelerinin araştırılması. TÜBiTAK, Doğa Dergisi, 12 (1): 48-74.

Özpınar A. \& A. Yücel. 2002. "Güneydoğu Anadolu Projesi (GAP) alanındaki pamuklarda zararlı ve avcı böcek türlerinin belirlenmesi”, 247-255. Türkiye 5. Biyolojik Mücadele Kongresi Bildirileri, 4-7 Eylül 2002, Erzurum. 
Özpınar, A., O. Çopur, H. Abrak \& M. A. Gür, 1988. Harran ovası'nda farklı ekim zamanı ve azot dozlarının kütlü pamuk verimi ve dikenlikurt'un bulaşıkık oranı üzerine etkisinin belirlenmesi. Harran Üniversitesi Ziraat Fakültesi Dergisi, 2(1): 7-14.

Özpınar, S. \& A. Isık, 2004 Effects of tillage, ridging and row spacing on seedling emergence and yield of cotton. Soil Research, 75: 19-26.

Şahin, A. \& I. Ekşi, 1987. Bazı pamuk çeşitlerinde ekim zamanlarının verim ve kalite üzerine etkisi. TKB Tarımsal Araştırmalar Genel Müdürlüğü. Nazilli Pamuk Araştırma Enstitüsü Sonuç Raporu: 68 s.

Venugopal, R. N., S. P. Raja, M. Venkataiah \& M. Rajasri, 1995. Influence of habitat on Helicoverpa armigera (Hubner) in cotton-ecosystem. Indian Journal of Plant Protection, 23 (2): 122-125.

Yurdakul, O. \& M. N. Ören, 1991. "Çukurova Bölgesi'nde pamuk üretim maliyeti, satış fiatı ve ekim alanı ilişkisi”, 3241. Çukurova I. Tarım Kongresi, 9-11 Ocak 1991, Adana. 